Arab Univ. J. Agric. Sci., Ain Shams Univ., Cairo, 14(2), 661-678, 2006

\title{
SURVIVABILITY OF ESCHERICHIA COLI 0157:H7 AND NON- 0157 SEROTYPES ISOLATED FROM SOME DAIRY PRODUCTS UNDER STRESS CONDITIONS
}

\section{[42]}

\author{
Zeinab I. Sadek ${ }^{1}$
}

\begin{abstract}
Microbiological assay of 150 samples of dairy products for the incidence of Coliforms, E. coli, E. coli 0157:H7 and non-0157 E.coli, show the recovery of the Coliforms and E.coli from the tested products with different incidence percentage. Strains of E. coli 0157:H7 and non-0157 E .coli were recovered from $9(6 \%)$ and $13(8.6 \%)$ of the total samples, respectively. The behaviour of these isolates were tested when exposing to low $\mathrm{pH}$, salt, low holding temperature and heat treatment. The results indicate obvious survival of E. coli 0157:H7 and non-0157serotype with $\mathrm{pH}$ as low as $3.8 \mathrm{pH}$ for 5 days. Also, survival or even multiplication in TSB containing $<6 \%$ salt. Moreover, the strains remained viable at low holding temperature $\left(5^{\circ} \mathrm{C}\right)$. So, the product which contaminated with this pathogens remain hazardous even under such stress condition. Decimal reduction times (D-values) of cells suspended in saline solution, TSB medium, reconctituted dry milk and chocolate milk were determined. The greatest survival as evidenced by highest $\mathrm{D}$ and $\mathrm{Z}$ values occurred with chocolate milk. Product composition and type of strain affected the heat lethality rates.
\end{abstract}

Keywords: Escherichia coli 0157:H7, non-0157 E. coli, pH, Salt, Heat resistance, Dairy products

\section{INTRODUCTION}

Most of Escherichia coli different strains are of special interest for its potential health hazard, as serotypes causing diarrhea or more serious forms of illness.

Enterohaemorrhagic E. coli (EHEC) is the most pathogenic strain among the verotoxin (VTEC) or shiga toxin producing E. coli. The illness caused by VTEC can range from self-limited, watery and bloody diarrhaea to life threatening manifestations such as haemolytic uraemic syndrome (HUS) or thrombotic thrombocytopenic purpura, which may result in human death (Padhye and Doyle, 1992). Although, a wide variety of VTEC serogroups has been implicated in human disease E. coli $0157: \mathrm{H} 7$ is the most prevalent strain.

Also, serotypes other than 0157:H7 (non-0157) such as 026, 0103, 0111and o145 have been identified as emergent

1- Dairy Department, National Research Centre, Dokki, Cairo, Egypt.

(Received July 5, 2006)

(Accepted July 16, 2006) 
human pathogen (McKee et al 2003). Several outbreaks were attributabe to serotypes 026:H11, 0111:H8 and 0121:H19 (Large et al 2005). Non- 0157 $E$. coli were also thought to have a low infections dose as E. coli 0157:H7 (Large et al 2005).

Survival of $E$.coli 0157:H7 already has been demonstrated in Cottage, Cheddar, Colby, Romano, Feta and soft cheeses, skimmlk; buttermilk; sourcream and yogurt (Arocha et al 1992; Guraya et al 1998; Reitsma and Henning 1996 and Ogwaro et al 2002). Also, non- 157 strains have been isolated from raw milk, ice cream, yoghurt, kareish, cheese, Domiati cheese and Ras cheese (ElAshmawy et al 2005 and Mckee et al 2003).

Acidity is an important parameter influencing the ability of pathogen to cause disease. Since its resistance to high acid and low pHs may permit the pathogen to survive in acid foods and acidic enviroment of the stomach.

The common use of $\mathrm{NaCl}$ to salten foods also creates attendance to suppress the potential pathogens by elevating $\mathrm{NaCl}$ concentrations.

Keeping low -temperature of foods is still the primary mean utilized to restrict the growth of bacteria and pathogens in foods .However, a group of pathogens were capable of growing at $5^{\circ} \mathrm{C}$ including E. coli (Palumbo et al 1997). E. coli 0157:H7 has been shown to survive in acidic foods stored at refrigeration temperature better than those at ambient temperature (Zhao et al 1993).

Providing a successful heat-treatment is a critical point for controlling $E$. coli in many manufactured foods. Data on heatresistance are therefore, essential to obtain a safe heat-treatment especially as refrigeration cannot be relied upon to prevent growth of this pathogen.

Therefore, the objective of this study is to detect the prevalence rates of $E$. coli 0157:H7 and non-157 E. coli strains in milk and some dairy products to assess their susceptibility to various environmental and food-related process factors such as acidity, salinity, keeping at low temperature and heat treatment.

This will be of great benefit for milk and milk products process, hygiene and keeping quality.

\section{MATERIAL AND METHODS}

\section{Samples collection}

Samples were collected from different dairy farms, super markets, retailar shops over one year period. One hundred and fifty samples (30 each of raw milk, butter, Domiati cheese, kareish cheese and ice cream)were delivered directly to the laboratory as required by American Public Health Association (A.P.H.A., 1992).

Eneumeration of Coliforms and E.coli and isolation of $E$. coli $0157: \mathrm{H7}$ and non-157 E. coli

Samples were enriched in MacConkey broth medium (El-Nokrashy et al 1992) and examined for incidence of total colifors in a set of 3 fermentation tube of MacConkey broth with inverted Durham's tube for collection of gas and incubated at $37^{\circ} \mathrm{C}$ for $48 \mathrm{~h}$. according to and a loopful from the positive tubes was streaked on levine's Eosin Methylene Blue agar and incubated at $44^{\circ} \mathrm{C}$ for 24h.and examied for typical colonies (metalhic-shiney green) of E.coli.Also, 0.1 $\mathrm{ml}$ was spread onto dried surface of $\mathrm{Ce}$ - 
fixime Tellurite Sorbitol MacConkey agar (CT.SMAC) (Oxiod),plates were incubated at $37^{\circ} \mathrm{c}$ for $24 \mathrm{hrs}$, (Zadik et al 1993) colourless colories were picked up and steaked onto Tryptone soya agar slants for identification of E.coli 0157:H7 and non-157 serogroups.

\section{Identification methods}

Identification methods were carried out according to Kreig and Holt (1991). The immunological detection system was used, which include E. coli 0157 latex agglutination test (Oxoid)and latex stide agglutination test for the detection of non-0157 serogroups (026, 091, 0103, 0111, 0128 and 0145) (Dry spot E. coli seroscreen (Oxoid).

\section{Preparation of inculum}

Isolates of $E$.coli $0157: \mathrm{H} 7$ and non157 E. coli were grown separately in TSB and incubaled at $37^{\circ} \mathrm{C}$,equal volumes of $18 \mathrm{~h}$ cultures of the isolated strain from the same source of dairy products were combined to serve as the inoculum for each experiment.

\section{pH tolerance}

Tryptone soy broth (TSB) was adjusted aseptically to $\mathrm{pH}$ values $(3.8,4.1$, 4.7, 5 and 5.5) with strile $85 \%$ lactic acid.TSB in different $\mathrm{pHs}$ were inoculated with $10^{5} \mathrm{CFU} / \mathrm{ml}$, kept at $10^{\circ} \mathrm{C}$ and analyzed after 2 and 5 days onto Violet Red Bile Agar (VRBA) (Oxoid). The experiment was carried out in doublicate.

\section{$\mathrm{NaCl}$ tolerance}

The experimental was similar to the $\mathrm{pH}$ study, but TSB medium was adjusted to $\mathrm{pH} 7$ and each containing amounts of $\mathrm{NaCl}$ to yield $0,2,4,6$ and $8 \%$.

\section{Minimum growth temperature}

The minimum growth temperature was determined by testing the isolates of E.coli 0157:H7 and non-157 serogroup in which grown as described before in TSB at temperature 10,8 and $5^{\circ} \mathrm{C}$ for 10 days at intervals of $0,3,5,7$ and 10 days. Aliquots of $E$. coli strains were determined for viable cell counts by plating on VRBA for determination of maximum population at the minimum temperature.

\section{Heat Resistance}

\section{a- Strain selection}

Isolates of $E$. coli $0157: \mathrm{H} 7$ and non157 serogroups were examined for their heat resistance in TSB.

Preliminary experiment were done by exposing all isolates (24h-old) to different heat treatments $\left(73^{\circ} \mathrm{C} / 15 \mathrm{sec}\right.$. and $60^{\circ} \mathrm{C} /$ $30 \mathrm{~min}$.). The preferable heat treatment to determine the heat-resistance parameters for the isolates was $60^{\circ} \mathrm{C} 10 \mathrm{~min}$. The most resistant 2 strains of each of $E$. coli 0157:H7 and non-157 serogroups were chosen to determine $\mathrm{D}$ and $\mathrm{Z}$-values.

Using the test tube method (Donnelly and Briggs, 1987), the two strains (24hold) were inoculated $(0.1 \mathrm{ml})$ into screwcapped test tubes containing $10 \mathrm{ml}$ of sterilized saline solution, TSB, reconstituted milk or chocolate milk, and heated at 55,60 and $65^{\circ} \mathrm{C}$ in a water bath began at the end of the come-up period, with dwell times at each temperature. Time/ Temperature treatments were carried out as follow:

$55^{\circ} \mathrm{C}: 10,20,30,40$ and $50 \mathrm{~min}$.

$60^{\circ} \mathrm{C}: 0.5,1,2,3,4,5,6$ and $10 \mathrm{~min}$. 
$65^{\circ} \mathrm{C}: 20,60,80,120,180,200$ and $240 \mathrm{sec}$.

\section{b- D and Z- value catculations}

Rates of thermal inactivation of each bacterium of $E$. coli $0157: \mathrm{H} 7$ and non157 serotypes were determined graphically by plotting the $\log _{10} \mathrm{cfu} / \mathrm{ml}$ of surviving cell population (detecting by using plate count agar) versus heating time for each temperature. The best fit line was drawn through the date points, and Dvalues were obtained from the slope of the best fit lines.Z-value of each bacterium was estimated by regressing $\log \mathrm{D}$ values versus heating temperatures (Ahmed et al 1995).

\section{RESULT AND DISCUSSION}

\section{Incidence of VTEC0157 and non-0157 VTEC in dairy products}

Results of the 150 tested samples of dairy products are listed in Table (1) for the presence of Coliforms,

E. coli, verocytotoxigenic $E$. coli (VTEC) 0157:H7 and non-0157 serotypes. Results indicated the high levels of contamination with Coliforms $(100 \%)$ in raw milk samples, which consequently indicates a probable sanitation problemes in farms, marketing and handling of raw milk.

Table 1. Incidence of coliforms and E. coli, VTEC-0157 and Non-0157 VTEC isolates in milk and some milk products.

\begin{tabular}{|c|c|c|c|c|c|c|c|c|c|}
\hline \multirow[b]{2}{*}{$\begin{array}{c}\text { Tested } \\
\text { samples }\end{array}$} & \multirow{2}{*}{$\begin{array}{c}\text { Total } \\
\text { No. } \\
\text { of sam- } \\
\text { ple }\end{array}$} & \multicolumn{2}{|c|}{ Total coliforms } & \multicolumn{2}{|c|}{ E. coli } & \multicolumn{2}{|c|}{ VTEC-0157 } & \multicolumn{2}{|c|}{ Non-0157 VTEC } \\
\hline & & $\begin{array}{c}\text { No. of } \\
\text { positive } \\
\text { samples }\end{array}$ & $\%$ & $\begin{array}{c}\text { No. of } \\
\text { positive } \\
\text { samples }\end{array}$ & $\%$ & $\begin{array}{c}\text { No. of } \\
\text { positive } \\
\text { samples }\end{array}$ & $\%$ & $\begin{array}{c}\text { No. of } \\
\text { positive } \\
\text { samples }\end{array}$ & $\%$ \\
\hline Raw milk & 30 & 30 & 100 & 24 & 80 & 3 & 10 & 2 & 6.6 \\
\hline Butter & 30 & 13 & 43.3 & 5 & 16.6 & 0 & 0 & 0 & 0 \\
\hline $\begin{array}{l}\text { Domiati } \\
\text { cheese }\end{array}$ & 30 & 20 & 66.6 & 8 & 26.6 & 2 & 6.6 & 2 & 6.6 \\
\hline $\begin{array}{l}\text { Kareish } \\
\text { cheese }\end{array}$ & 30 & 25 & 83.3 & 19 & 63.3 & 3 & 10 & 6 & 20 \\
\hline Ice cream & 30 & 9 & 30 & 6 & 20 & 1 & 3.3 & 3 & 6.6 \\
\hline Total & 150 & 97 & 64.6 & 62 & 41.3 & 9 & 6 & 13 & 8.6 \\
\hline $\begin{array}{l}\text { Total No. of } \\
\text { Total No. of }\end{array}$ & $\begin{array}{l}\text { coli } 015 \\
\text { on }-E \text {. co }\end{array}$ & $\begin{array}{l}7: \mathrm{H} 7 \text { isola } \\
\text { li } 0157: \mathrm{H}^{\prime}\end{array}$ & $\begin{array}{l}\text { tes }=1 \\
\text { isolate }\end{array}$ & $s=20$ & & & & & \\
\hline
\end{tabular}


Also, raw milk samples showed high incidence of VTEC 0157 (10\%) and non157 VTEC (6.6\%). Similar results were obtained by Abdul-Roouf et al (1996) who reported that $6 \%$ of raw cows' milk samples examined in Egypt were contaminated with E. coli 0157:H7. Moreover, Massa et al (1999) recorded a good survival or even multiplication of $E$. coli 0157:H7 in raw milk when stored at $8^{\circ} \mathrm{C}$.

Although these organisms would not be expected to survive pasteurization of raw milk the cheeses made from this milk might represent a health hazard if the pathogen was there and survived the cheese making process, Hereupon the prevalence rates of coliforms, E. coli 0157:H7 and non 0157 type were high in Kareish cheese $(83,10$ and 20\%, respectively). While in Domiati cheese the incidence percent was $66.6 \%$ coliforms and $6.6 \%$ for each of VTEC 0157 and non0157 types. Known enterotoxigenic stains have been shown to survive during manufacture of brick and Camembert cheeses (Glatz and Brudvig, 1980), Cheddar Cheese (Reitsma and Hening, 1996), Domiati and Kareish (Ahmed et al 1988 and Abd-El-Hady et al 1995) and Cottage cheese (Arocha et al 1992). Moreover, Hussein and Sakuma (2005) reported that $E$. coli $0157:$ H7 not only survived the manufacturing process of Comembert and feta cheeses but increased in number at the end of storage period.

E. coli $0157: \mathrm{H} 7$ and non-157 serogroups failed be to detected in butter samples (Table 1).

This was may be due to physical characteristics and low water activity in this product limits survival and growth of $E$. coli. The minimum water activity for growth of Eschericha species is 0.95
(Glatz and Brudvig, 1980) well above the water activity of butter.

Ice cream samples (Table 1) had lowest percentage of Coliforms and only one of the 30 ice cream samples $(3.3 \%)$ contained VTEC-0157 but three samples $(10 \%)$ were positive for non-0157 VTEC. The non-0157 VTEC are more frequently present in food of animal origin than serotype 0157 (Neill, 1997). El-Ashmawy et al (2005) could isolate VTEC 0157:H7 and non-0157 from ice cream samples in lower percentages ( $2 \%$ for each strain).

\section{Acidity tolerance}

The survival and growth respones of isolates of $E$. coli $157: \mathrm{H} 7$ to different $\mathrm{pHs}$ (3.8-5.5) were illustrated in Figs. (1 \& 2), as indicator for acidity tolerance. At $\mathrm{pH}$ 3.8, the isolated strains of E.coli 0157:H7 toleraled such a low $\mathrm{pH}$ in 2 days incubation and survived but with sharp rate of decline at the $5^{\text {th }}$ day of incubation.

The bacteria count at $\mathrm{pH} 4.1$ exhibited $\sim 2-\log$ reduction after 5 days of incubation of the isolated strains from different tested dairy products. Survival with no growth was observed at PH 4.4 after 2 and 5 days of incubation of all of the tested strains of E. coli 0157:H7. Therefore; the results indicated that the tested strains may grow and increase in counts between $\mathrm{pH} 5$ and 5.5 as low acid to neutral medium. While, these were decline in number below pH 5 in the high acid medium across 2-days. Difference in cell densities at different $\mathrm{pH}$ level were observed between the strains isolated from different samples of tested dairy products. In this respect, Zhao et al (1993) reported that this pathogen grew slightly in apple cider at pH 3.8 to 4 , indicating more acid 


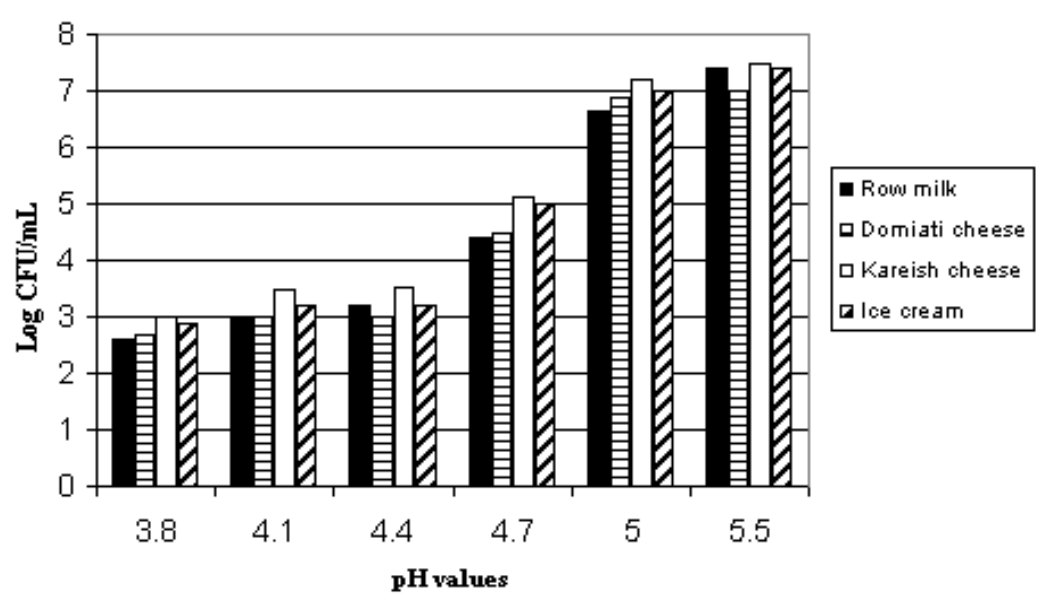

Fig. 1. Growth response of isolated strains of E. coli $0157: \mathrm{H} 7$ in TBS at varying $\mathrm{pH}$ levels at $10^{\circ} \mathrm{C}$ for $48 \mathrm{~h}$.

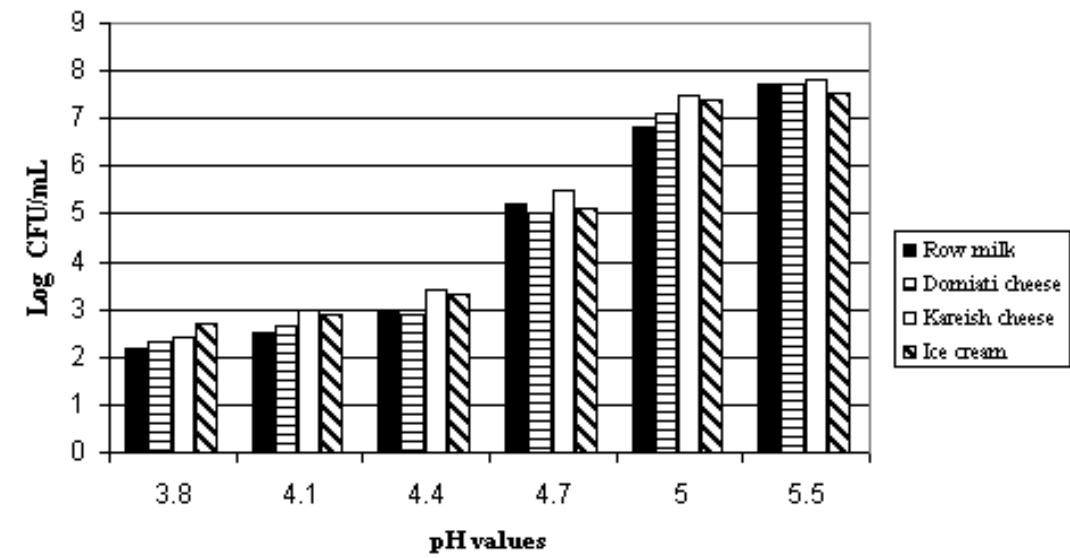

Fig. 2. Growth response of isolated strains of E. coli $0157: \mathrm{H} 7$ in TBS at varying $\mathrm{pH}$ levels at $10^{\circ} \mathrm{C}$ for $48 \mathrm{~h}$. 
tolerance than observed in this study. Also, Besser et al (1993) noticed survival of $E$. coli $0157: \mathrm{H} 7$ at $8^{\circ} \mathrm{C}$ for 20 days in freshly pressed apple cider with $\mathrm{pH}$ below 4.Moreover, Guraya et al (1998) found that $E$. coli $0157: \mathrm{H} 7$ was survived at $\mathrm{pH} 3.8$ in skin milk for 7 days and was not detected at $\mathrm{pH} 4.4$ after 35 days and in butter milk, sour cream, and yogurt, $E$. coli $0157: \mathrm{H} 7$ was inactivated at rates similar to or greater than those for skimmilk. Moreover, Hussein and Sakuma (2005) reported that E.coli 0157:H7 survived in yogurt and sour cream at low $\mathrm{pH}$ values (4.17and 4.3, respectively). In contrarly, Guraya et al (1998) reported that E. coli 0157:H7 did not survive in skim milk at pH 3.8 and was reduced by 3-log cycles at $\mathrm{pH} 4.1$.

On the other hand, strins of $E$. coli 0157:H7 isolated from Kariesh cheese achieved higher densities compared with the other studied strains for the both 2 and 5-day incubation period in all $\mathrm{pH}$ values.

The survival and or growth of isolated E. coli non157in TBS adjusted to various $\mathrm{pH}$ values for 2 and 5-days incubation at $10^{\circ} \mathrm{C}$ are shown in Figs. (3 \& 4).

There is a decrease in the viable courts of all of the isolated strains at $\mathrm{pH}$ values 4 and 3.8. While, viable courts increased in TBS at pHs 5.5 and 5, whereas, the organism grew up to $\sim 2-\log$ cycles at pH5 after 2-days incubation and more after 5-days.Slight differences were observed in rates of inactivation, survival and growth at different $\mathrm{pH}$ values between the strains isolated from different samples of diary products. In general, strains of $E$. coli $0157: \mathrm{H} 7$ vary widely in their acid tolerance (Miller and Kasper, 1994 and Massa et al 1997).
It should be pointed out that the isolated strain of non-0157 E. coli have less ability to survive in acidic media than isolated strains of $E$. coli $0157: \mathrm{H} 7$. In this respect, Large et al (2005) reported out breaks associated with non-157 E. coli was much less frequently than $E$. coli 0157:H7 and the reason for this disparity in prevalence may result from the differences in the inherent acid resistance and survival in acidic food between the two types. Also, Eblen et al (2005) reported that strains other than E. coli 0157:H7 do not have the high acid resistance reported for E.coli 0157:H7.

Generally, acid survival plays an important role in bacterial enteric infections. Food borne pathogens must survive in the stomach $(\mathrm{pH}<3)$. The data indicate that products at or below pH 4 could be good vehicles of $E$. coli $0157: \mathrm{H7}$ and non 157 strains.

\section{Salt tolerance}

In the presence of $\mathrm{NaCl}$, the range of growth of E. coli 0157:H7 was between $2-4 \% \mathrm{NaCl}$, and this rate was decline with $6 \% \mathrm{NaCl}$ during 2 and 5-days incubation in TSB at $10^{\circ} \mathrm{C}$ (Fig. 5). Where as at $8 \% \mathrm{NaCl}$, counts of the pathogen decreased. Differant isolated strains exhibited varying growth rates and tolerance ranges over the two periods of incubation. Optimum $\mathrm{NaCl}$ levels seems to be $0-2$ $\mathrm{NaCl}$ for the different isolated strains of E. coli $0157: \mathrm{H} 7$ on the basis of the maximum counts that was observed at these levels. Other investigations indicated that E.coli $0157: \mathrm{H} 7$ was moderately salt tolerant and survives at $6.5 \% \mathrm{NaCl}$ (Glass et al 1992 \& Gibson and Roberts, 1986). Also, Guraya et al (1998) observed E.coli population reduction in $6 \%$ salted 


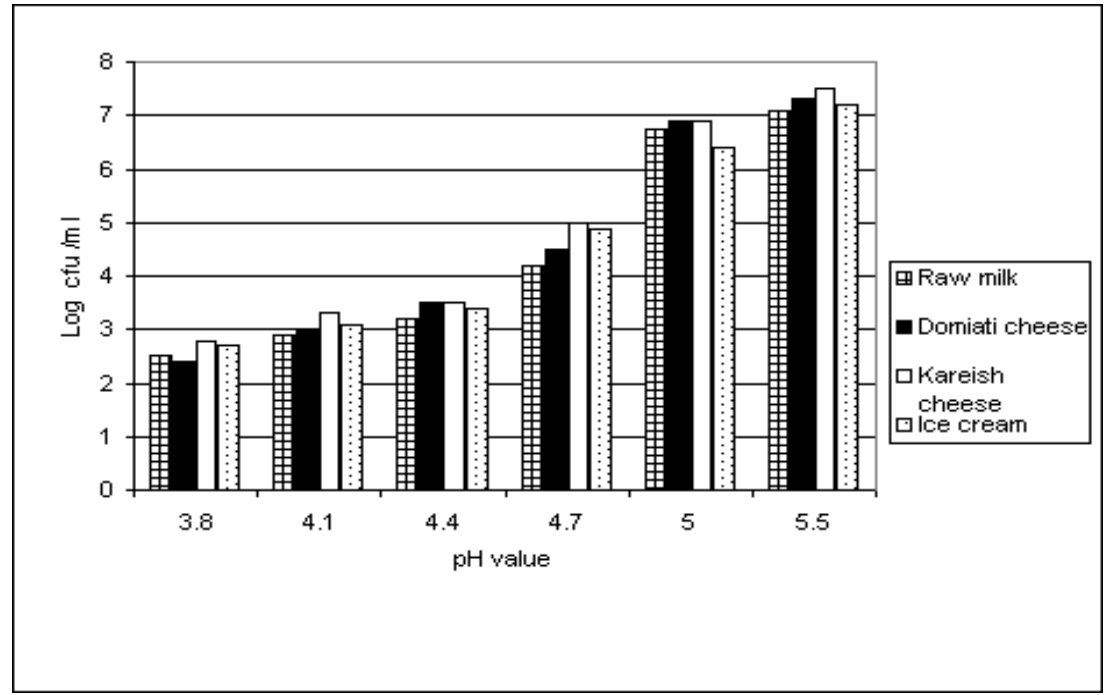

Fig. 3. Growth response of isolated strains of non-0157:H7 E. coli in TBS at varying $\mathrm{pH}$ levels at $10^{\circ} \mathrm{C}$ for 2 days.

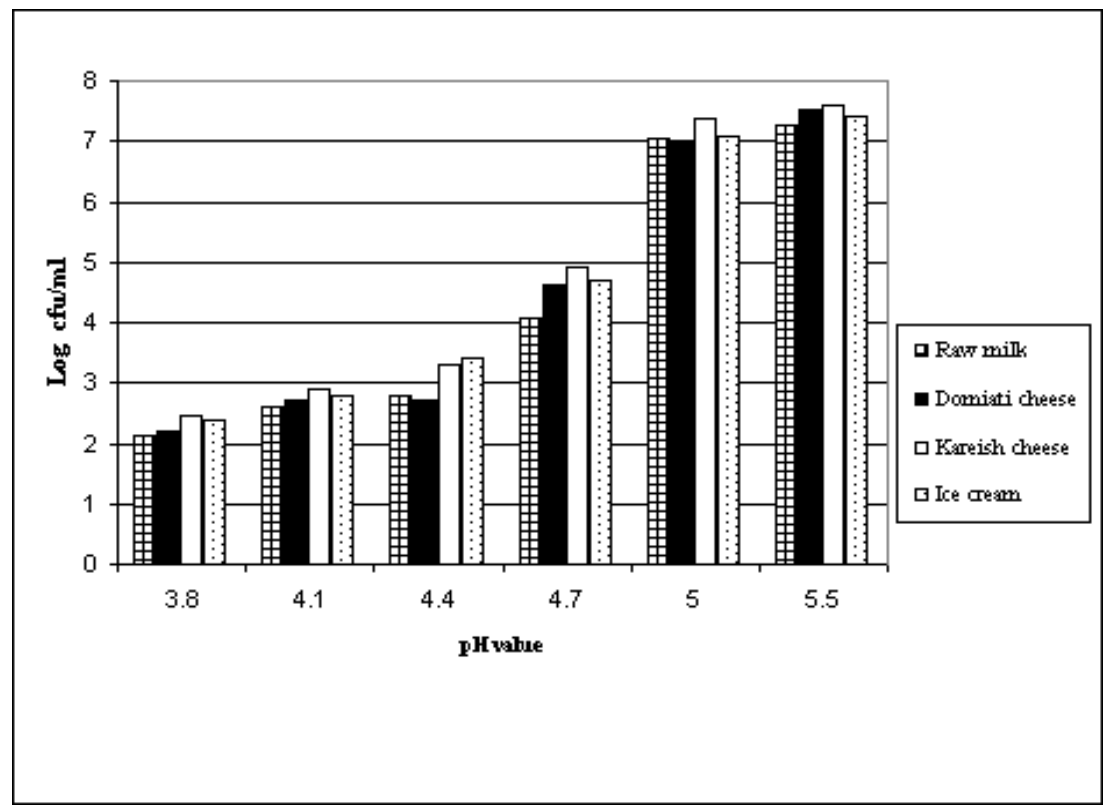

Fig. 4. Growth response of isolated strains of non-0157:H7 E. coli in TBS at varying pH levels at $10^{\circ} \mathrm{C}$ for 2 days. 
(A) Isolated from raw milk

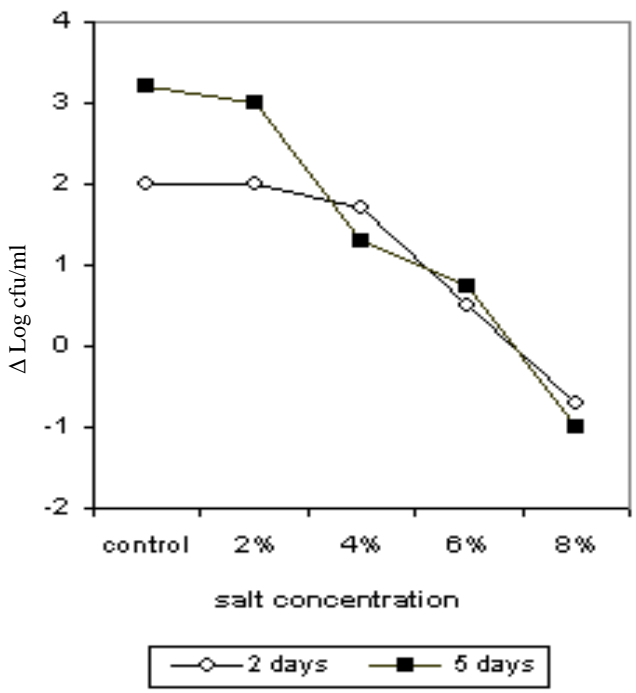

(C) Isolated from Kariesh cheese

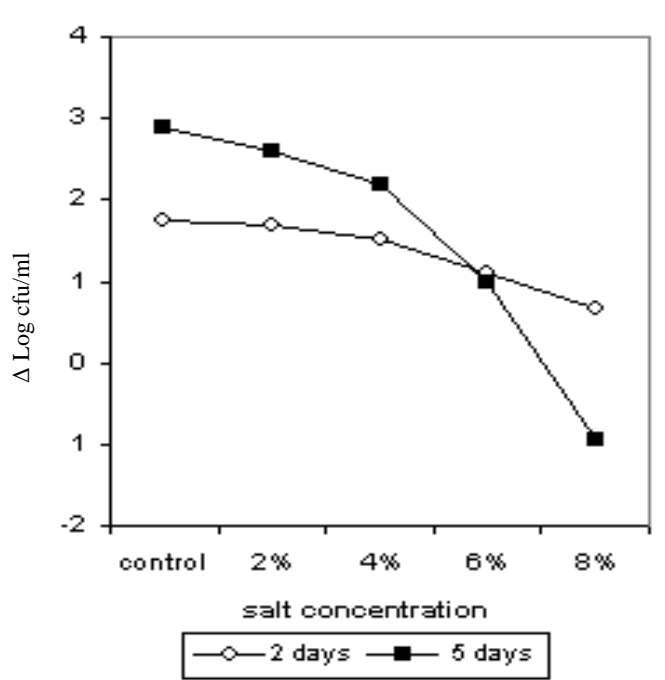

(B) Isolated from Domiati cheese

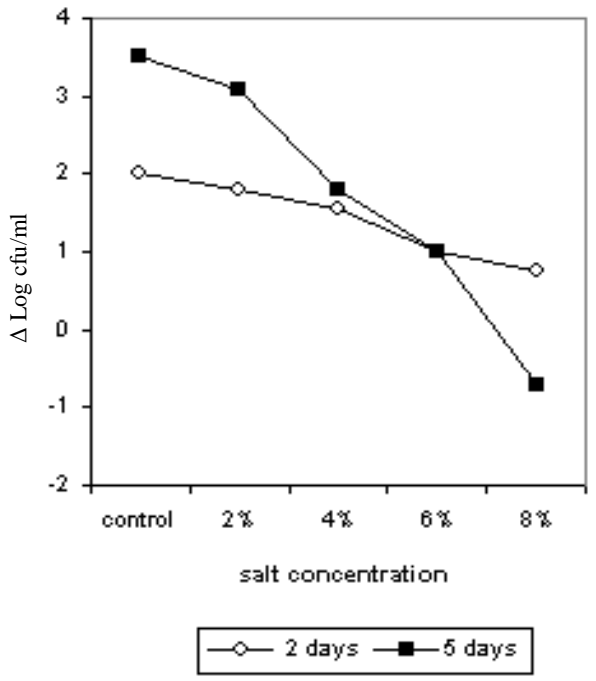

(D) Isolated from Ice cream

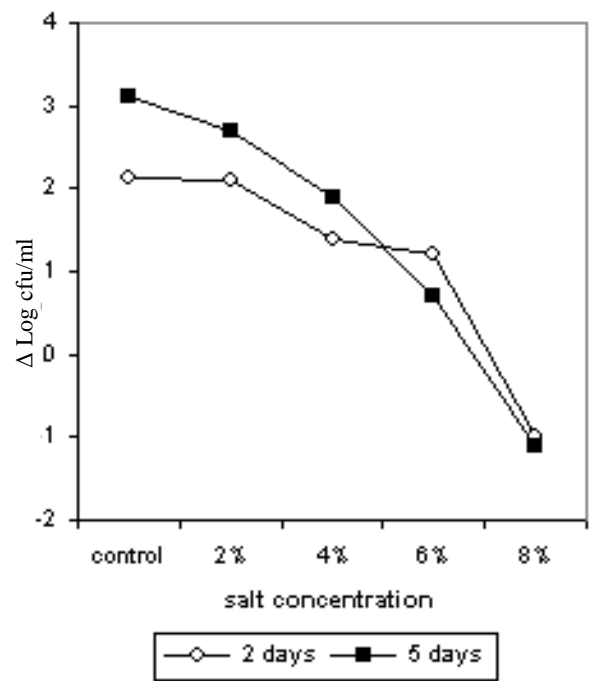

Fig. 5. Behavior of isolated strains of E. coli $0157: \mathrm{H} 7$ in TSB at varying concentration of $\mathrm{NaCl}$ for 2 and 5 days at $10^{\circ} \mathrm{C}$. 
dairy food samples at $\mathrm{pH} 5$ and 5.4. They reported that there was greater survival at lower salt levels of 2 and $4 \%$.

The isolated strains of non-157 E. coli behaved similarly with different concentrations of $\mathrm{NaCl}$ to TSB during the incubation periods of 2 and 5 days at $10^{\circ} \mathrm{C}$ strains grew in $\mathrm{NaCl}$ different concentrations up to $6 \%$, but a reduction of viable counts was appeared at $8 \% \mathrm{NaCl}$, as shown in Fig. (6). These results are in agreement with those obtained by Conner and Hall (1996) who reported that 6 or $8 \% \mathrm{NaCl}$ in TSB showed a pronounced effect on growth of the pathognic E. coli during storage at $10^{\circ} \mathrm{C}$.

\section{Low temperature effects}

The ability of the isolated strains of $E$. coli 0157:H7 and non-157 E. coli to grow at low temperature in TSB as maximum populations counts at the lowest temperature are shown in Table (2). All of the tested strains grew well at $10^{\circ} \mathrm{C}$ and increased in numbers in average more than $3 \log$ cycles of the four strains of $E$. coli 0157:H7 and non-157 E. coli in a holding period of 10 -days. At $8^{\circ} \mathrm{C}$, all of the four strains of E. coli $0157: \mathrm{H} 7$ were able to grow and attain maximum counts in 5-7 days. While isolates of non-157 E. coli attained maximum counts after 7-10 days of holding period; except the E. coli strains isolated from ice cream which reached maximum populations after 5 days. This is may be attributed to the adaptation of these strains to grow of low temperatures. In this concern, it has been reported that certain sub-optimum environmental condition may result in protection from subsequent stresses (Semanchek and Golden, 1998). However, all of the tested isolates survived during the holding period of 10-days (Table 2). Thus a problem might come up since some strains of enterohemorrhagic E.coli could grow at low temperature $\left(8^{\circ} \mathrm{C}\right)$ and produce verotoxin (Palumbo et al 1997). There is no conflict with the finding of Guraya et al (1998) who noticed better survival at $4{ }^{\circ} \mathrm{C}$ than at $12{ }^{\circ} \mathrm{C}$ in acidic media. Also, Massa et al (1999) and Jones et al (2006) who obtained good survival of $E$. coli $0157: \mathrm{H} 7$ in raw milk stored at 6 and $8^{\circ} \mathrm{C}$.

Hereupon, the milk products contaminated with E. coli 0157:H7 and non-157 E. coli would remain hazard for consumption even if held at $5^{\circ} \mathrm{C}$.

Table 2. Growth respones and lowest temperature for growth and survival of E. coli 0157:H7 and non- 0157 E. coli isolates.

\begin{tabular}{|lcccc|}
\hline \multirow{1}{*}{ Isolates } & $\begin{array}{c}\text { Lowest temperature }\left({ }^{\circ} \mathrm{C} \text { ) at }\right. \\
\text { which growth occurred }\end{array}$ & $\begin{array}{c}\text { Time (days) to attain } \\
\text { maximum population }\end{array}$ \\
\cline { 2 - 5 } & E. coli $0157:$ H7 Non -0157 E.coli & E. coli $0157:$ H7 & Non -0157 E.coli \\
\hline Milk & 8 & 8 & 5 & 7 \\
Domiati cheese & 8 & 8 & 7 & 10 \\
Kareish cheese & 8 & 8 & 7 & 7 \\
Ice cream & 8 & 8 & 5 & 5 \\
\hline
\end{tabular}

* No growth but survived at $5^{\circ} \mathrm{C}$ 
(A) Isolated from raw millk

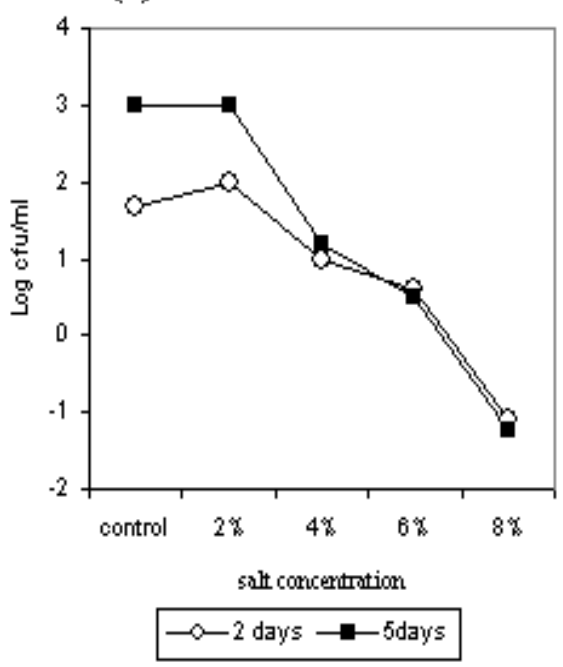

(C) Isolated from Kariesh cheese

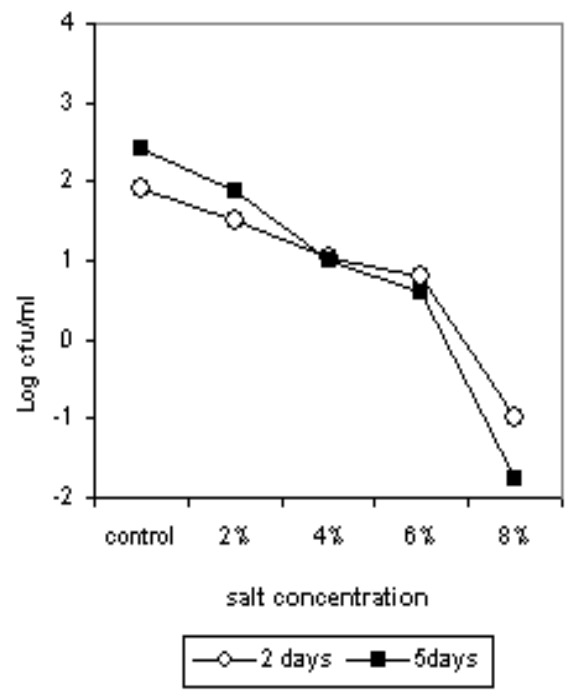

(B) isolated from Domiati cheese

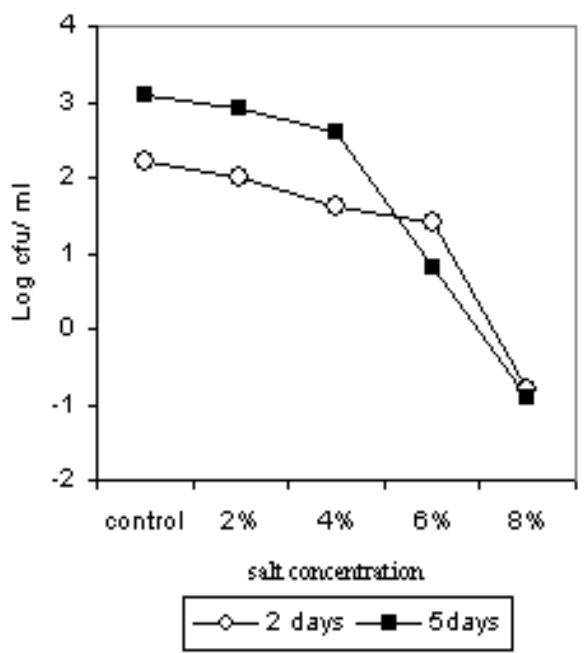

(D) Isolated from Ice cream

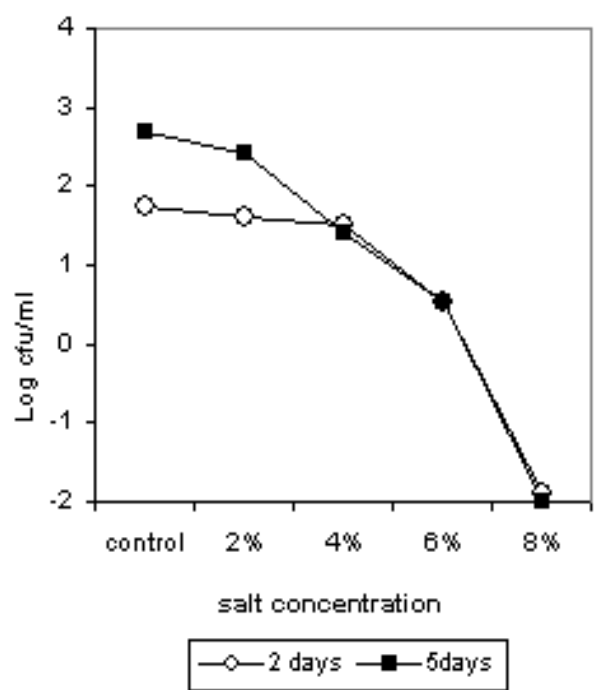

Fig. 6. Behavior of isolated strains of non- 0157:H7 E. coli in TSB at varying concentration of $\mathrm{NaCl}$ for 2 and 5 days at $10^{\circ} \mathrm{C}$. 


\section{Thermal inactivation studies}

Determination of heat resistance revealed that all of the tested isolates showed no heat resistance to the pasteurization temperature $\left(65^{\circ} \mathrm{C} / 30 \mathrm{~min}\right.$ and $72^{\circ} \mathrm{C}$ for $15 \mathrm{sec}$.) which were sufficient to kill either of the E. coli $0157: \mathrm{H} 7$ and non0157 E. coli. These results were in agreement with those obtained by Massa et al (1999) who reported that high temperature short time $\left(71.7^{\circ} \mathrm{C}, 15 \mathrm{sec}\right)$, was sufficient to kill approximately $1 \times 10^{5} \mathrm{E}$. coli $0157: \mathrm{H} 7 \mathrm{ml}^{-1}$.

Also the different strains of $E$. coli 0157:H7 and also non-157 E. coli vary in their tolerance to heat inactivation (Fig. 7 \& 8).

The results obtained for $\mathrm{D}$ and $\mathrm{Z}$ values of the two selected strains belonging to E. coli $0157: \mathrm{H} 7$ and non-157 E. coli are shown in Table (3). The recorded Dvalue at $55^{\circ} \mathrm{C}$ of $E$. coli $0157: \mathrm{H} 7$ ranged from $16.8 \mathrm{~min}$, in saline solution to $26.5 \mathrm{~min}$ in milk chocolate. While, Dvalue at $60^{\circ} \mathrm{C}$ ranged from 3.7 to 5.2 min. for saline solution and chocolate milk, respectively. Also, $D_{65}$ values ranged from $1.0 \mathrm{~min}$. in saline solution to $1.5 \mathrm{~min}$. in reconstituted dry milk and chocolate milk (Table 3). Thus, the resultant $\mathrm{D}$ values were high order in chocolate milk >milk> TSB medium> saline. This may be due to the presence of $\mathrm{NaCl}$ $9 \%$ in saline solution, the nutrient factors in TSB medium and the carbohydrates, protein, fat contents in milk and milk products (Semanchek and Golden, 1998; Ahmed et al 1995 and Duffy et al 2006).

D-values obtained were close, but not identical to those reported by Line $\boldsymbol{e t}$ al (1991); Ahmed et al (1995); Kotrola and Conner (1997) and Huang \& June- ja (2003). This is due to the ecological difference between the strains or isolates, the methodology and different recovery media or different products concerning the heat resistance of selected strain of $E$. coli, non-0157 serotypes, result D-values were shown in Table (3).

The $\mathrm{D}_{55}$ values ranged from 19.5 to 24 min.; in saline solution and chocolate milk, respectively.

At $60^{\circ} \mathrm{C}$, the $\mathrm{D}$ values were $5.9,6.2$, 7.2 and $7.5 \mathrm{~min}$. for saline solution, TSB, reconstituted milk and chocolate milk, respectively. While, increasing the heat treatment to $65 \mathrm{C}$ resulted in reduction in all of the $\mathrm{D}$-values when the $\mathrm{D}_{65}$ values ranged from $1.2 \mathrm{~min}$ in saline solution to $1.6 \mathrm{~min}$.in chocolate milk comparing.

The obtained results D-values for the different selected strains of $E$. coli 0157:H7 and non-0157 E. coli are shown in (Table 3).

It was observed that the different strains varied in their sensitivity to lethal effecty of different heating temperatures, the same heating temp/time and heating media.

This might reflect difference in the heat resistance of strains of 0157 and non 0157 serogroups under the same condition. Clavero and Beuchat (1996) found that non-0157:H7 E. coli strains were less heat resistant than $E$. coli 0157:H7 strains. Williams and Ingham (1997) obtained D- value at $54^{\circ} \mathrm{C}$ for $E$. coli FRIK-124 was fivefold lower than the Dvalue of $E$. coli $0157: \mathrm{H} 7$.

The Z-values were estimated by the linear regression between $\log$ (D) and temp. were ranged from 7.8 to $8^{\circ} \mathrm{C}$ for E.coli $0157: \mathrm{H} 7$, and were ranged from 8.1 to $8.7^{\circ} \mathrm{C}$ for non- 0157 serotypes in different media. These values were similar to the value obtained by Huang and 


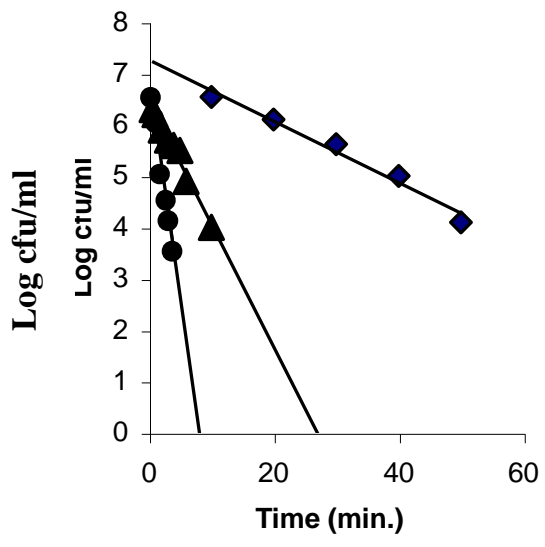

(A) in saline solution

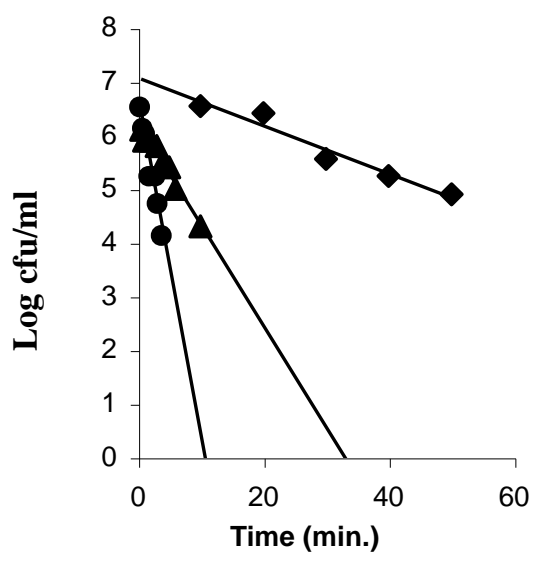

(C) in milk

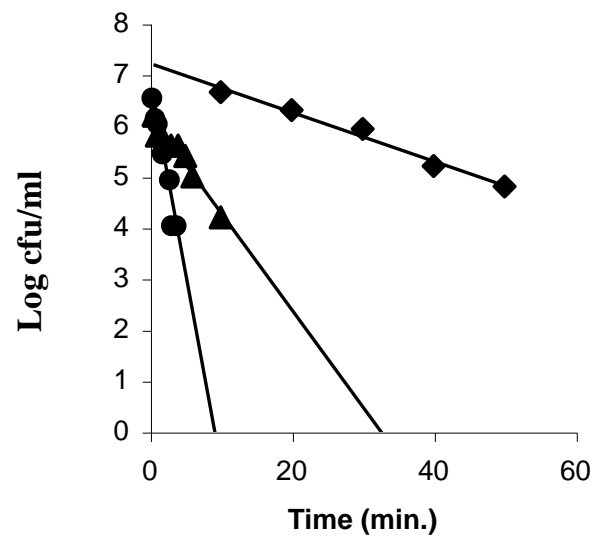

(B) in TSB medium

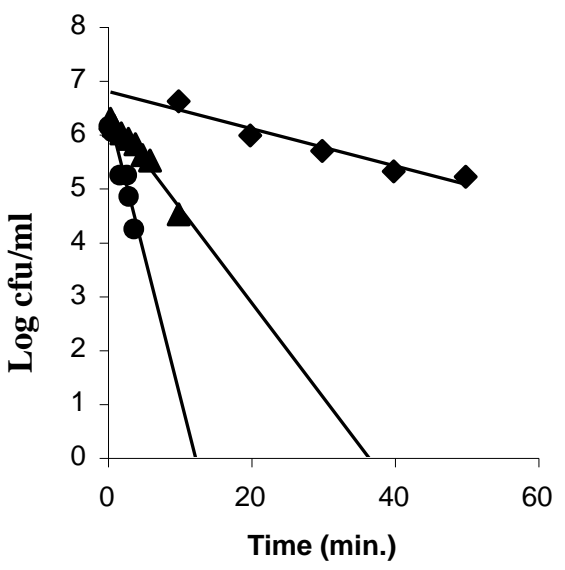

(D) in chocolate milk

$$
\text { - } 55^{\circ} \mathrm{C} \quad \boldsymbol{\Delta} 60{ }^{\circ} \mathrm{C} \bullet 65^{\circ} \mathrm{C}
$$

Fig. 7. Representative survivor curves of the chosen isolated E.coli 0157:H7 at different temperatures 
Zeinab Sadek

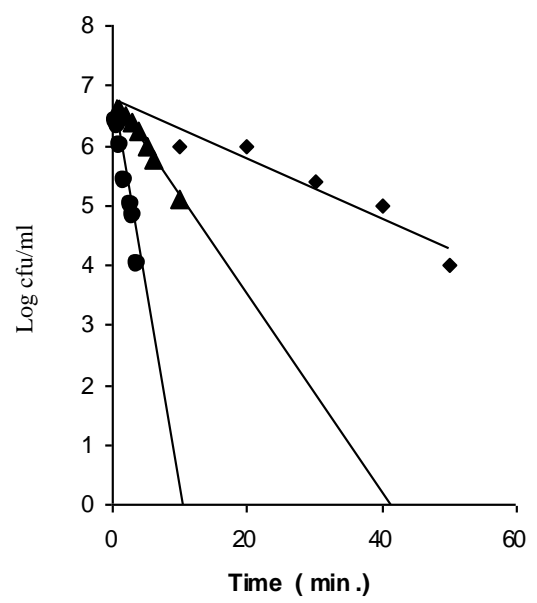

(A) in saline solution

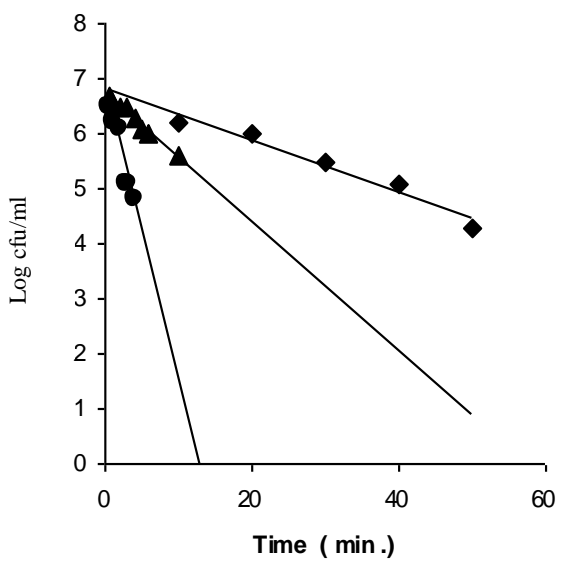

(C) in milk

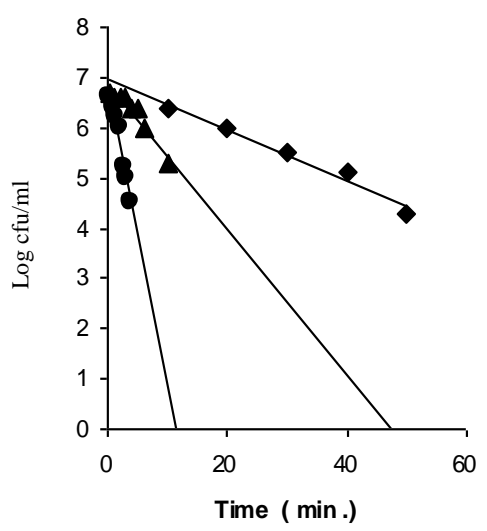

(B) in TSB medium

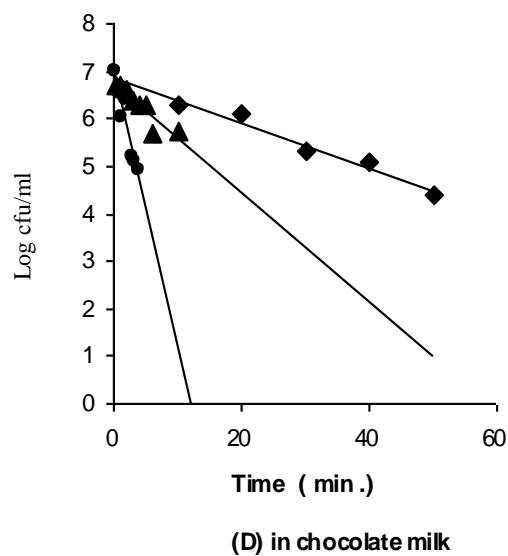

- $55{ }^{\circ} \mathrm{C} \quad \boldsymbol{\Delta} 600^{\circ} \mathrm{C} \quad \bullet 65^{\circ} \mathrm{C}$

Fig. 8. Representative survivor curves of the chosen isolated non-E.coli 0157:H7 at different temperatures. 
Table 3. D- values (minutes) and Z-values $\left({ }^{\circ} \mathrm{C}\right)$ of E.coli 0157:H7 and non - 0157 Serogroups in different media.

\begin{tabular}{|cccccccccc|}
\hline & \multicolumn{7}{c|}{ D-values (minutes) } \\
\cline { 2 - 9 } Temp. & \multicolumn{7}{c|}{ E.coli 0157} & \multicolumn{7}{c}{ non -0157 serogroups } \\
\cline { 2 - 10 } & Saline & TSB & Milk & $\begin{array}{c}\text { Chocolate } \\
\text { milk }\end{array}$ & Saline & TSB & Milk & $\begin{array}{c}\text { Chocolate } \\
\text { milk }\end{array}$ \\
\hline $55^{\circ} \mathrm{C}$ & 16.8 & 19.2 & 22.4 & 26.4 & 19.5 & 20 & 22 & 24 \\
$60^{\circ} \mathrm{C}$ & 3.7 & 4.0 & 4.3 & 5.2 & 5.9 & 6.2 & 7.2 & 7.5 \\
$65^{\circ} \mathrm{C}$ & 1.0 & 1.1 & 1.1 & 1.5 & 1.2 & 1.5 & 1.6 & 1.6 \\
& 7.8 & 7.9 & 7.9 & 8.0 & 8.1 & 8.6 & 8.7 & 8.7 \\
\hline
\end{tabular}

Juneja (2003), but higher than values $\left(6^{\circ} \mathrm{C}\right)$ obtained by Juneja et al (1997) and (4.34-4.78 $\left.{ }^{\circ} \mathrm{C}\right)$ obtained by Ahmed et al (1995).

In conclusion, it is worthy to announce the survival and growth patterns of E. coli $0157: \mathrm{H} 7$ and non-0157 serotypes to reduce its hazardous in milk and milk products. Milk pasteurization is queit enough to destroy these microbes and secure the customers's heath.

\section{REFERENCES}

Abd-El-Hady, H.M.; M.A. Halawa and S.H. EL-Shenawy (1995). Surveillance of enterohemorrhagic E. coli in milks and Kareish cheese. Assiut Vet. Med. J. 33: 110-112.

Abdul-Raouf, U.M.; M.S. Ammar and L.R. Beuchat (1996). Isolation of Echerichia coli 0157: H7 from some Egyptian foods. Int. J. Food Microbiol, 29:423426.

Ahmed, A.A.H.; S.H. Ahmed and M.K. Moustafa (1988). Occurrence of fecal coliforms and enterophathogenic Escherichia in Egyptian salt cheese. J. Food Prot. 51: 442-444.

Ahmed, N.H.; D.E. Conner and D.L. Huffman (1995) .Heat-resistance of Escherichia coli 0157:H7 in Meat and poultry as affected by product composition. J. Food Sci., 60: 606-610.

American Public Health Association (A.P.H.A.) (1992). Compendium of Methods for the Microbiological Examination of Food. Third Ed. pp.843-845, American Public Health Association, Washington D.C., USA.

Arocha, M.M.; M. Mcvey; S.D. Londer; J.H. Rupnow and L. Bullerman (1992). Behavior of hemorrhagic Escherichia coli 0157:H7 during the manufacture of Cottage cheese. J. Food Prot., 55: 379-381.

Besser, R.E.; S.M. Lett; J.T. Weber; M.P. Doyle; T.J. Barrett and J.G. Wells (1993). An outbreak of Diarrhea and hemolytic uremic syndrome from fresh-pressed apple cider. JAMA 296: 2217. 
Clavero, M.R. and L.R. Beuchat (1996). Survival of Escherichia coli 0157:H7 in broth and processed Salami as influenced by $\mathrm{pH}$,water activity,and temperature and suitability of media for its recovery. Appl. Environ. Microbial. 62: 2735-2740.

Conner, D.E. and G.S. Hall (1996). Temperature and food additives affect growth and survival of Escherichia coli 0157:H7 in poultry meat. Dairy,Food and Environmental Sanitation 16: 150153.

Donnelly, C.W. and E.H. Briggs (1987). Comparison of heat resistance of Listeria monocytogenes in milk by two methods. J. Food Prot. 50: 14-19.

Duffy, G.; C. Walsh; I.S. Blair and D.A.M.C. Dowell (2006). Survival of antibiotic resistant an antibiotic sensitive strains of E. coli 0157 and E. coli 026 in food matrices. Int. J. Food Microbiol 109: 179-186.

Eblen, D.R.; B.A. Annous and G.M. Sapers (2005). Studies to select appropriate nonpathogenic surrogate Esherichia coli strains for potential use in place of Esherichia coli 0157:H7 and salmonella in pilot plant studies. J. Food Prot., 68: 282-291.

El-Ashmawy, M.A.M.; M. El-Sherbini and A. Abd El-Khalak (2005). The prevalence of verocytotoxigenic Escherichia coli and its significance in milk and some diary products. $4^{\text {th }}$ Int. Sci. Conf. Mansoura, 1187-1197.

El-Nokrashy, S.; A.G. Hegazi; N.F. Tawfeek; L. Aly; M.A. El-Shenawy; B.A. Effat and R.K. El-Dairouty (1992). comparative study on selective media used in recovering enteropathogenic E. coli. J. Egypt Vet. Med. Ass. 52: 483-492.
Gibson, A.M. and T.A. Roberts (1986). The effect of $\mathrm{pH}$, Water activity,sodium nitrate and storge temperature on the growth of Enteropathogenic Esherichia coli and salmonella in a laboratory medium. Int. J. Food Micobiol., 6:155-178. Glass, K.A.; J.M. Loefielholz; J.P. Ford and M.P. Doyle (1992). Fate of Escherichia coli 0157:H7 as affected by $\mathrm{pH}$ or sodium chloride and in fermented dry sousage. Appl. Environ. Microbiol. 58: 2513-2516.

Glatz, B.A. and S.A. Brudvig (1980). Survey of commercially available cheese for Enterotoxigenic Escherichia coli .J. Food Prot., 43: 395-398.

Guraya, R.; J.F. Frank and A.N. Hassan (1998). Effectiveness of Salt, $\mathrm{pH}$ and Diacetyle as inhibitors for Escherichia coli in dairy foods stored at refrigeration temperature. J. Food Prot.,61:1098-1102. Huang, L. and V.K. Juneja (2003). Thermal Inactivation of Escherichia coli 0157:H7 in Ground Beef supplemented with sodium lactale. J. Food Prot. 60: 664-667.

Hussein, S.H. and T. Sakuma (2005). Shiga toxin - producing Echerichia coli: pre and postharvest control Measures to Ensure safety of Dairy cattle products. $\boldsymbol{J}$. Food Prot., 68: 199-207.

Jones, T.H.; A. Murray; M. Johns; C.O. Gill and L.M. McMullen (2006). Differential expression of proteins in cold-adapted log-phase cultures of Escherichia coli incubated at 8,6 or $2^{\circ} \mathrm{C}$. Int. J. Food Microbiol., 107: 12-19.

Juneja, V.K.; O.P. Snyder and B.S. Marmer (1997). Theremal destruction of Escherichia coli 0157:H7 in beef and chicken: determination of D-and Zvalues. Int. J. Food Microbiol. 35: 231237. 
Kotrola J.S. and D.E. Conner (1997). Heat Inactiviation of Escherichia coli 0157:H7 in Turkey Meat as Affected by Sodium chloride, Sodium lactate, polyphosphate, and Fat content. J. Food Prot. 60: 898-902.

Krieg, N.R. and J.G. Holt (1991). Bergeys Manual of Systematic Bacteriology. Volume II, pp. 420-423. Williams and Wilkins, Baltimore, USA.

Large, T.M.; S.T. Walk and T.S. Whittan (2005). Variation in Acid Resistance among shiga toxin-producing clones of pathogenic Esherichia coli Appl. and Environ. Microbiol .71:2493-2500.

Line, J.E.; A.R Fain; A.B. Moran; L.M. Martin; R.V. Lechowich; J.M. Carosella and W.L. Brown (1991). Lethality of heat to Escherichia coli 0157:H7: D-value and z-value determination in ground beef. J. Food Prot. 54: 762-766.

Massa, S.; C. Attieri; V. Quaranta and R. De Pace (1997). Survival of E. coli 0157:H7 in yoghurt during preparation and storage at $4{ }^{\circ} \mathrm{C}$. Lett. Appl. Microbiol., 24: 347-350

Massa, S.; E. Goffredo; C. Attier and K. Natola (1999). Fate of Escherichia coli $0157:$ H7 in unpasteurized milk stored at $8^{\circ}$ C. Lett. Appl. Microbiol., 28: 8992.

Mckee, R.; R.H. Madden and A. Gilmour (2003). Occurrence of verocytotoxin producing Esherichia coli in Dairy and Meat processing environments. J. Food Prot., 66: 1576-1580.

Miller, L.G. and C.W. Kaspar (1994). Escherichia coli 0157:H7 acid tolerance and survival in apple cider. J. Food Prot. 57: 460-464.
Neill, M.A. (1997) .Overview of verotoxigenic Escherichia coli. J. Food Prot., 60:1444-1446.

Ogwaro, B.A.; H. Gibson; M. Whitehead and D.J. Hill (2002). Survival of Escherichia coli $0157 ; \mathrm{H} 7$ in traditional African yoghurt fermentation. Int. J. Food Microbiol., 79:105-112.

Padhye, N.V. and M.P. Doyle (1992). Escherichia coli 0157:H7 epidemiology ,pathogenesis and methods for detection in Foods. J. Food Prot., 55: 555-565.

Palumbo, S.A.; A. Pickard and J.E. Call (1997). Population changes and verotoxin production of Enterohemorrhagic E.coli strains inoculated in milk and ground beef held at low temperature. $\boldsymbol{J}$. Food Prot., 60: 746-750.

Reitsma, C.J. and D.R. Henning (1996). Survival of Enterohemorrhagic Escherichia coli 0157:H7 during manufacture and curing of Cheddar J. Food Prot., 59: 460-464.

Semanchek, J.J. and D.A. Golden (1998). Influence of growth temperature on inactivation and injury of Escherichia coli $0157: \mathrm{H} 7$ by heat, acid and freezing. J. Food Prot., 61: 395-401.

Williams, N.C. and S.C. Ingham (1997). Changes in heat resistance of Escherichia coli 0157:H7 following heat shock. J. Food Prot., 60: 1128-1131.

Zhao, T.M.; M.P. Doyle and R. Besser (1993). Fate of Enterohaemorrhagic Escherichia coli 0157:H7 in apple cider with and without preservatives. Appl. Environ. Microbiol., 59: 252-2530.

Zadik, P.M.; P.A. Chapmanand; C.A. Siddons (1993). Use of tellurite for the selection of verocytotoxigenic Esherichhia coli 0157. J. Medical Microbiol. 39: 155-158. 
بحلة اتحاد الجامعات العربية للدراسات والبحوث الزراعية، جامعة عين شمس، القاهرة، 14(2)، 661-678، 2006 قدرة سلالات الميكرويين Escherichia coli 0157:H7 و المعزوله من منتجات الآلبان على البقاء تحت الظروف غير المناسبة للنمو

[42]

\author{
زينب ابراهيم صادق 1 \\ 1. قسم الالبان المركز القومى للبحوث- الدقى - القاهرة- مصر
}

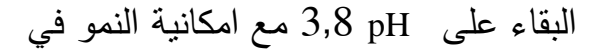

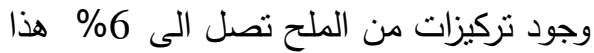

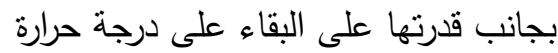

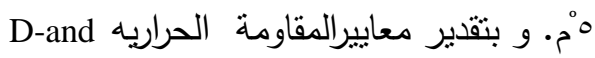
Z- values

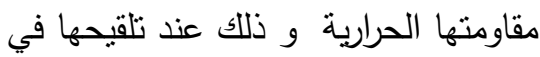
محلول ملحى وبيئة ببنون صويا السائله

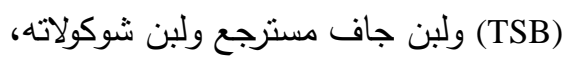

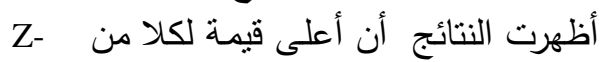
and D- values

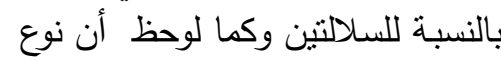

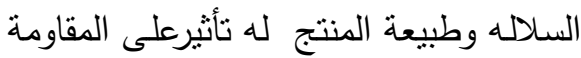

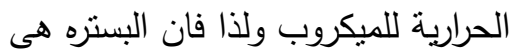

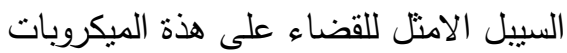
وضمان تأمين صحة المستهلك.
تم فحص 150 عينة من اللبن الخام - التحني

الزبد- الجبن القريش-الجبن الدمياطيالايس كريم ميكروبيولوجيا لوجود مجموعة الفين

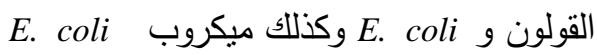

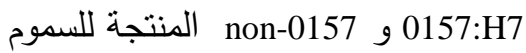
والمسببة للأ سهال المدمم ،حيث تم عزل سلالات الميكروبين الاخيرين من عينات المات اللبن الخام و الجبن القريش و الجبن

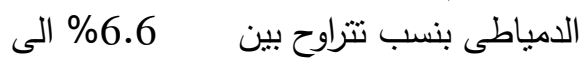

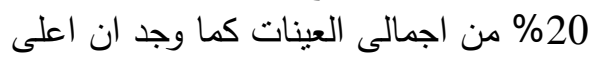

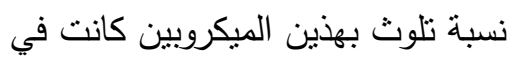
عينات الجبن القريش. بدراسة سلوكها وقدرتها علي النمو والبقاء

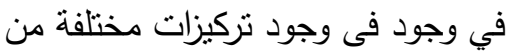
الحموضة والملح وكذلك درجات الحرارة المنخفضة وتأثير المعامله الحرارية، وجد ان ان النران كلا الميكروبين يستطيع ونايز المعائ

تحكيم: $1 . د$ محمد نبيل إبراهيم المجدوب

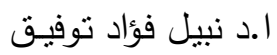

